\title{
PEMANFAATAN SAMPAH ORGANIK UNTUK PENGOLAHAN KOMPOS
}

\author{
Retno Wulan Sekarsari', Nurifatul Halifah'2, Trisnawati Hasdiah Rahman ${ }^{3}$, Anis \\ Jauharotul Farida ${ }^{4}$, Makdum Ibrahim Asmara Kandi ${ }^{5}$, Estining Apsari Nurfadilla ${ }^{3}$, \\ Mohammad Miftahul Anwar6, Fakhri Fansuri Almu', Surya Ariansyah Arroji6, Dana \\ Fauzana Arifaldi6, Zuhriatul Fuadah ${ }^{2}$ \\ ${ }^{1}$ Fakultas Ilmu Administrasi, Universitas Islam Malang \\ ${ }^{2}$ Fakultas Agama Islam, Universitas Islam Malang \\ ${ }^{3}$ Fakultas Keguruan dan Ilmu Pendidikan, Universitas Islam Malang \\ ${ }^{4}$ Fakultas Ekonomi dan Bisnis, Universitas Islam Malang \\ ${ }^{5}$ Fakultas Peternakan, Universitas Islam Malang \\ ${ }^{6}$ Fakultas Teknik, Universitas Islam Malang \\ Korespondensi email: sekarsari@unisma.ac.id
}

\begin{abstract}
ABSTRAK
Meningkatnya jumlah penduduk dan kegiatan manusia dalam suatu daerah maka semakin tinggi jumlah sampah yang dihasilkan. Dibutuhkan cara pengelolaan yang lebih baik agar sampah tidak menjadi masalah bagi lingkungan. Pola pengelolaan sampah dengan cara pengumpulan, pengangkutan serta pembuangan di tempat akhir sampah tidak dapat menyelesaikan persoalan ini. Disamping berbiaya tinggi pola ini juga menghasilkan volume sampah yang dibuang tidak terkurangi, diketahui bahwa TPA memiliki daya tampung dan usia pemakaian maksimal. Pengabdian ini bertujuan untuk mengidentifikasikan komposisi sampah di salah satu sumber penghasil sampah yaitu rumah penduduk Desa Wonoayu Kecamatan Wajak, serta memberikan solusi lebih ekonomis dan efisien dalam penanganan sampah yang dihasilkan khususnya sampah organik. Metode yang dilaksanakan menggunakan eksperimen dengan subjek sampah organik yang dihasilkan dari rumah penduduk. Bahan kompos yang terbaik untuk dilakukan proses pengomposan adalah sampah sayur plus kotoran ternak dengan penambahan $10 \mathrm{ml}$ EM-4 (kompos variasi A). Dukungan warga masyarakat terutama Wanita Tani Desa dan Ibu-Ibu PKK serta remaja sangat diharapkan untuk melaksanakan dan melanjutkan program ini.
\end{abstract}

Kata Kunci: sampah penduduk; bioaktivator; lubang kompos.

\section{PENDAHULUAN}

Limbah padat dari buangan pasar dihasilkan dalam jumlah yang cukup besar. Limbah tersebut berupa limbah sayuran yang hanya ditumpuk di tempat pembuangan dan menunggu pemulung untuk mengambilnya atau dibuang ke TPA jika tumpukan sudah meninggi. Penumpukan yang terlalu lama dapat mengakibatkan pencemaran, yaitu bersarangnya hama-hama dan timbulnya bau yang tidak diinginkan. Sampah organik merupakan bahan buangan yang biasanya dibuang secara open dumping tanpa pengelolaan lebih lanjut sehingga akan menimbulkan gangguan lingkungan dan bau yang tidak sedap (Sholihah \& Nurhidayati, 2018; Elamin et al., 2018). Berdasarkan hal tersebut diatas, perlu diterapkan suatu teknologi untuk mengatasi limbah padat, yaitu dengan menggunakan teknologi daur ulang limbah padat menjadi produk kompos yang bernilai guna tinggi. Pengomposan dianggap sebagai teknologi berkelanjutan karena bertujuan untuk 
konservasi lingkungan, keselamatan manusia, dan pemberi nilai ekonomi (Djuwendah, 2005). Penggunaan kompos membantu konservasi lingkungan dengan mereduksi penggunaan pupuk kimia yang dapat menyebabkan degradasi lahan. Pengomposan secara tidak langsung juga membantu keselamatan manusia dengan mencegah pembuangan limbah organic (Cahyani \& A., 2013).

Tujuan dalam program ini adalah untuk mengetahui kandungan $\mathrm{C}, \mathrm{N}$, dan rasio $\mathrm{C} / \mathrm{N}$ kompos matang dan mengetahui komposisi yang terbaik dari campuran bahan kompos yang sesuai dengan SNI-7030-2004. Proses pengomposan adalah proses dekomposisi materi organik menjadi pupuk kompos melalui reaksi biologis mikroorganisme secara aerobik dalam kondisi terkendali. Pengomposan sendiri merupakan proses penguraian senyawa-senyawa yang terkandung dalam sisa-sisa bahan organik (seperti jerami, daundaunan, sampah rumah tangga, dan sebagainya) dengan suatu perlakuan khusus. Hampir semua bahan yang pernah hidup, tanaman atau hewan akan membusuk dalam tumpukan kompos (Rahmawati et al., 2017; Alawy \& Pujiwati, 2018).

Kompos sebagai hasil dari pengomposan dan merupakan salah satu pupuk organik yang memiliki fungsi penting terutama dalam bidang pertanian antara lain: Pupuk organik mengandung unsur hara makro dan mikro. Pupuk organik dapat memperbaiki struktur tanah. Meningkatkan daya serap tanah terhadap air dan zat hara, memperbesar daya ikat tanah berpasir. Memperbaiki drainase dan tata udara di dalam tanah. Membantu proses pelapukan dalam tanah (Intara et al., 2011; Sholihah \& Nurhidayati, 2018). Tanaman yang menggunakan pupuk organik lebih tahan terhadap penyakit. Proses pembuatan kompos berlangsung dengan menjaga keseimbangan kandungan nutrien, kadar air, $\mathrm{pH}$, temperatur dan aerasi yang optimal melalui penyiraman dan pembalikan (Suwatanti \& Widiyaningrum, 2017). Pada tahap awal proses pengkomposan, temperatur kompos akan mencapai 65-70 oC sehingga organisma patogen, seperti bakteri, virus dan parasit, bibit penyakit tanaman serta bibit gulma yang berada pada limbah yang dikomposkan akan mati. Dan pada kondisi tersebut gas-gas yang berbahaya dan baunya menyengat tidak akan muncul. Proses pengkomposan umumnya berakhir setelah 6 sampai 7 minggu yang ditandai dengan tercapainya suhu terendah yang konstan dan kestabilan materi.

Pupuk Organik adalah pupuk yang sebagian besar atau seluruhnya terdiri dari bahan organik yang berasal dari tanaman dan hewan yang telah mengalami rekayasa berbentuk padat atau cair yang digunakan untuk memasok bahan organik, memiliki sifat fisik, kimia, dan biologi tanah (Dewanto et al., 2017). Pupuk organik merupakan hasil akhir dan hasil antara dari perubahan atau penguraian bagian dari sisa tanaman dan hewan. Pupuk organik berasal dari bahan organik yang mengandung berbagai macam unsur, meskipun ditandai dengan adanya Nitrogen dalam bentuk persenyawaan organik, sehingga mudah diserap tanaman.

Sampah organik dapat diolah menjadi pupuk dengan menggunakan proses fermentasi. Pupuk organik yang dibuat dengan menggunakan proses fermentasi disebut dengan kompos. Kompos merupakan istilah untuk pupuk organik yang dibuat oleh manusia melalui proses pembusukkan sisa-sisa buangan makhluk hidup (tanaman maupun hewan). Secara keseluruhan, proses pengomposan ini bisa disebut juga dengan dekomposi.

Kompos dan kegiatan pengomposan sudah tidak asing bagi masyarakat. Pengetahuan tentang kompos dan pengomposan telah diketahui secara turun menurun. Di kalangan petani dahulu penggunaan kompos sudah menjadi pemahaman kearifan lokal. Namun, disayangkan pembuatan kompos secara tradisional maupun alami membutuhkan waktu yang sangat lama. Dengan memanfaatkan teknologi kita dapat mempercepat pembuatan kompos dengan mengatur tiap kondisi pengomposan dan penambahan komposter. 
Teknik pengomposan teknologi rendah masih menggunakan cara-cara tradisional untuk membantu proses fermentasi bahan organik menjadi kompos. Proses pengomposan bahan organik juga tergolong memakan waktu yang cukup lama karena proses pengomposan bersifat alami (Trivana \& Pradhana, 2017). Dialam terbuka, pembentukan unsur kompos seperti pembentukan humus melalui proses pelapukan dengan bantuan bakteri yang terdapat di sekitar lingkungan pengomposan dan cuaca.

Teknik pengomposan yang termasuk kelompok ini adalah Windrow Composting. Bahan organik ditumpukan dalam barisan tumpukan yang disusun sejajar. Tumpukan secara berkala dibolah-balik dengan cara manual dengan alat tradisional untuk meningkatkan aerasi, menurunkan suhu apabila terlalu tinggi dan menurunkan kelembapan kompos. Teknik ini sesuai untuk pengomposan skala besar. Lama pengomposan berkisar berkisar antara 3 sampai 6 bulan, yang tergantung pada karakteristik bahan organik yang dikomposkan.

\section{METODE}

Metode yang digunakan adalah eksperimen yang sesungguhnya apabila penulis dapat mengontrol semua variabel luar yang mempengaruhi jalannya eksperimen, dengan demikian validitas penelitian menjadi tinggi. Program ini dilaksanakan diwilayah Pemerintahan Desa Wonoayu Kecamatan Wajak Kabupaten Malang. Dalam mengatasi permasalahan tersebut diatas, maka kegiatan yang digunakan supaya program dapat berjalan dan berkelanjutan yaitu melalui program sosialisasi mengenai proker yang dilakukan dengan pihak Pemerintah Desa dan pihak Kelompok Wanita Tani (KWT) di Desa Wonoayu untuk mencari mitra pembenahan fasilitas kedepannya. Kemudian dilanjutkan dengan eksekusi kegiatan proker yang sudah disetujui oleh mitra dan diakhiri dengan promosi hasil. Adapun tahapan pelaksanaan ini melalui tahap persiapan dan tahap pelaksanaan. Pada tahap pelaksanaan, dilakukan kegiatan sesuai perencanaan awal selama 4 minggu meliputi tahap sosialisasi pada pekan pertama, dilakukan observasi tempat cikal bakal pembuatan kompos, serta tahap pembuatan hingga finishing secara berturut-turut pada pekan kedua dan keempat.

Bahan-bahan yang diperlukan pada proses pembuatan kompos antara lain: sampah sayur, ampas tebu, kotoran ternak, dan EM-4. Sebelum pengomposan dilaksanakan terlebih dahulu dilakukan uji pendahuluan untuk mengetahui karakteristik dari limbah sayuran, ampas tebu, dan kotoran kambing, yang meliputi nilai $\mathrm{C}, \mathrm{N}$, rasio $\mathrm{C} / \mathrm{N}$, kadar air, temperatur, dan $\mathrm{pH}$.

\section{HASIL DAN PEMBAHASAN}

Pengelolaan sampah menjadi kompos sendiri bertujuan untuk mengurangi banyaknya volume sampah yang ada di Desa Wonoayu yang kemudian akan dimanfaatkan sebagai pupuk untuk para warga Desa Wonoayu yang notabene warganya adalah kelompok tani. Menurut hasil penelitian Handayani (2009) berdasarkan hasil uji Duncan, pupuk cacing (vermicompost) memberikan hasil pertumbuhan yang terbaik pada pertumbuhan bibit Salam (Eugenia polyanthaWight) pada media tanam subsoil. Indikatornya terdapat pada diameter batang, dan sebagainya. Hasil penelitian juga menunjukkan bahwa penambahan pupuk anorganik tidak memberikan efek apapun pada pertumbuhan bibit, mengingat media tanam subsoilmerupakan media tanam dengan $\mathrm{pH}$ yang rendah sehingga penyerapan hara tidak optimal. Pemberian kompos akan menambah bahan organik tanah sehingga meningkatkan kapasitas tukar kation tanah dan memengaruhi serapan hara oleh tanah, walau tanah dalam keadaan masam. Pengolahan hasil kompos dari sampah organik ini juga harus memerhatikan kemampuan dan tingkat 
penerimaan masyarakat setempat yang akan dikembangkan menjadi bahan tambahan para masyarakat tani desa.

Pelaksanaan tahap KKN-PPM tematik ini melalui beberapa tahapan yaitu tahap persiapan, tahap pelaksanan serta tahap pelaporan. Pada tahap pelaksanaan, dilakukan kegiatan sesuai perencanaan awal selama 4 minggu meliputi tahap sosialisasi pada pekan pertama, dilanjutkan tahap pengoalahan kompos dan promosi hasil pada pekan kedua dan keempat.

\section{Tahap Sosialisasi}

Kegiatan awal yang dilakukan di Desa Wonoayu Kecamatan Wajak adalah sosialisasi dengan Kelompok Wanita Tani (KWT) Desa dan ibu-ibu PKK. Sebelum diadakan sosialisasi dengan para Kelompok Wanita Tani (KWT) Desa dan PKK, kami menemui para pihak Pemerintah Desa dan berbicara mengenai kegiatan yang akan dilakukan selama 1 bulan di Desa Wonoayu serta rencana kami melaksanakan kegiatan Sosialisasi yang akan dilaksanakan di Balai Desa pada tanggal 5 Februari 2020. Kegiatan sosialisasi dilaksanakan untuk mencari mitra juga meminta izin untuk pembuatan lubang di sekitar daerah greenhouse sebagai tempat pembuatan kompos.

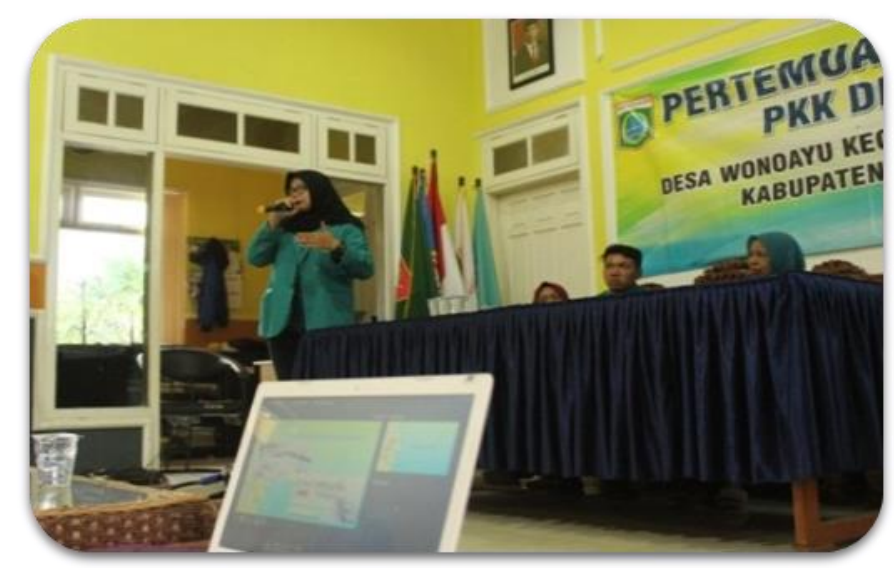

Gambar 1. Kegiatan sosialisasi dihadapan Ibu-Ibu PKK.

\section{Tahap Penggalian Lubang Untuk Tempat Pengolahan Kompos}

Pembuatan lubang di belakang greenhouse bertujuan sebagai tempat pembuangan sampah organik yang akan dijadikan kompos. Dan untuk meminimalisir pengeluaran kelompok. Tanah juga mengandung zat pengurai yang bagus dan cepat sebagai pembuatan kompos.

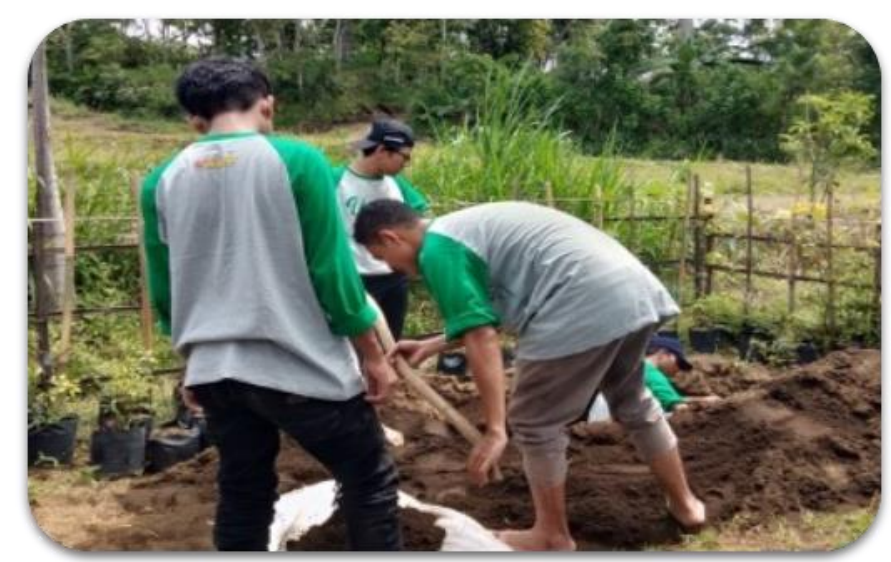

Gambar 2. Pembuatan Lubang Pembuangan Sampah Organik 
Dalam tahap ini, kegiatan selanjutnya yang akan dilakukan adalah pengambilan sampah organik di setiap rumah warga. Disini, kami mengambil sampel 15 rumah yang kita datangi setiap seminggu sekali. Setiap sampah yang sudah didapatkan masih akan dipilah dan dicacah menjadi potongan-potongan kecil, yang bertujuan agar mempercepat proses penguraian menjadi kompos. Lalu, sampah yang sudah dipilah dan dicacah dimasukkan kedalam lubang yang sudah dibuat sebelumnya dan akan dilanjutkan dengan pemberian EM4, tetes tebu, air, dan pupuk kandang kering. Kemudian kompos akan ditutup rapat dengan plastic dan akan ditunggu hasilnya hingga 2 minggu kedepan.

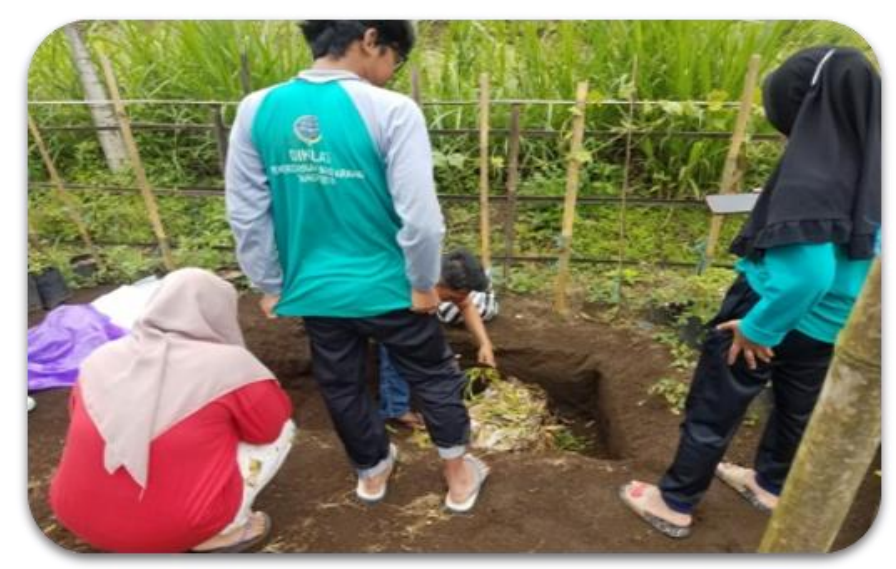

Gambar 3. Proses Penguraian Sampah

Dan penambahan cairan EM-4 juga pupuk kandang sebagai bahan campuran pembuatan kompos.

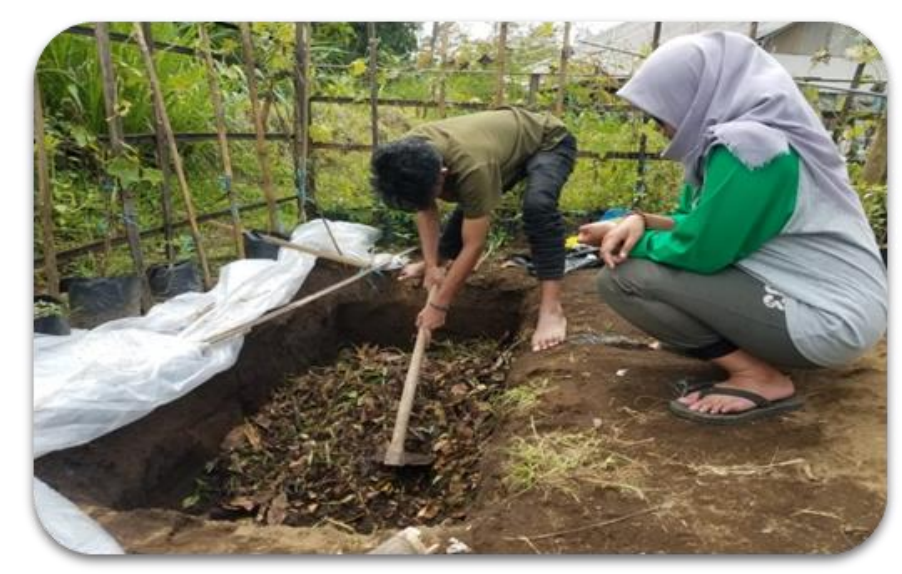

Gambar 4. Proses Penambahan Bahan Campuran

\section{Tahap Promosi dan Finishing}

Hasil dari pembuatan kompos organik ini gagal, dikarenakan cuaca di Desa Wonoayu Kecamatan Wajak ini yang sering turun hujan. Jadi, air masuk kedalam lubang dan merembes mengenai kompos. Karena kompos tidak bisa terkena air yang berlebihan karena akan menghambat pertumbuhan bakteri didalamnya, dan akan menyebabkan kompos menjadi tidak panas lagi. 


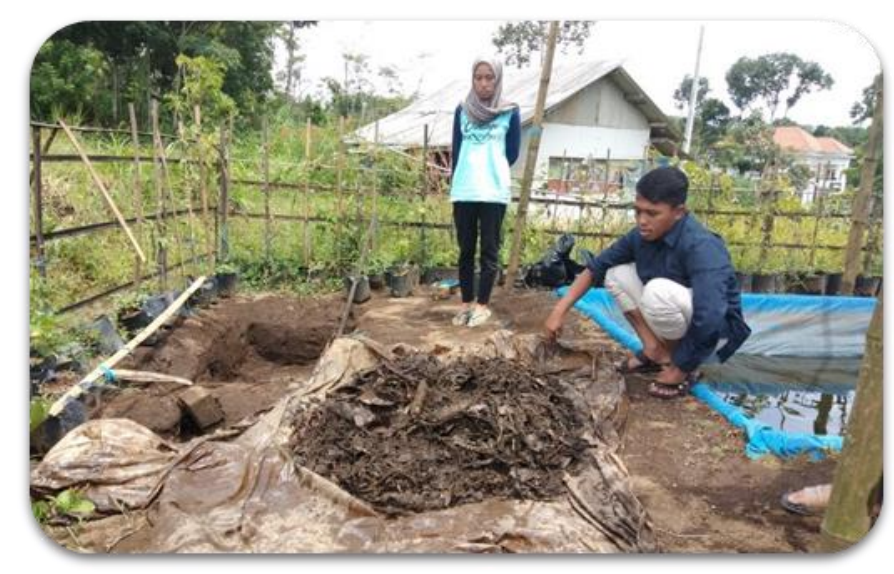

Gambar 5. Proses Pengomposan yang Gagal

\section{KESIMPULAN}

Bahan kompos yang terbaik untuk dilakukan proses pengomposan adalah sampah sayur plus kotoran ternak dengan penambahan $10 \mathrm{ml}$ EM-4 (kompos variasi A). Karakteristi kompos variasi A telah memenuhi standar SNI 19-7030-2004 dengan rasio C/N 17,45, kadar air 49,71, dan pH 7 dengan waktu kematangan 30 hari. Pelaksanaan program kerja KKN PPM Tematik dalam pengelolaan sampah menunjang ekonomi kreatif di Desa Wonoayu Kecamatan Wajak melalui pembuatan pupuk kompos mendapat respon yang sangat positif dan sangat didukung oleh masyarakat Desa Wonoayu. Meskipun hasil yang dicapai tidak sesuai dengan ekspektasi kelompok kami karena permasalahan cuaca yang tidak mendukung. Tapi, pengalaman yang kami dapatkan selama proses pembuatan pupuk kompos ini sangat berharga. Diharapkan masyarakat Desa Wonoayu Kecamatan Wajak dapat melanjutkan program-program yang telah dirintis mahasiswa KKN UNISMA. Dukungan warga masyarakat terutama Wanita Tani Desa dan Ibu-Ibu PKK serta remaja sangat kami harapkan untuk melaksanakan dan melanjutkan program/ kegiatan tersebut dalam mewujudkan Desa Wisata Wonoayu.

\section{DAFTAR RUJUKAN}

Alawy, T., \& Pujiwati, I. (2018). Pengembangan Biogas Kotoran Sapi di Kel. Kedopok Kec. Kedopok Probolinggo. Jurnal Inovasi Hasil Pengabdian Masyarakat (JIPEMAS), 1(1), 21-24. https://doi.org/10.33474/jipemas.v1i1.1475

Cahyani, D. A., \& A., R. M. P. (2013). Laju Aerasi Pada Pengomposan Limbah Sayuran Menggunakan Komposter Dengan Pengaduk Putar. Sainteks, 10(2), 9-21. https://doi.org/10.30595/sainteks.v10i2.146

Dewanto, F. G., Londok, J. J. M. R., Tuturoong, R. A. V., \& Kaunang, W. B. (2017). Pengaruh Pemupukan Anorganik Dan Organik Terhadap Produksi Tanaman Jagung Sebagai Sumber Pakan. Jurnal Zootec, 32(5), 1-8. https://doi.org/10.35792/zot.32.5.2013.982

Djuwendah, E. (2005). Keragaan Sosial Ekonomi Usaha Daur Ulang dan Pengomposan Sampah di Kotamadya Bandung. Jurnal Sosiohumaniora, 7(3), 248-263. https://doi.org/10.24198/sosiohumaniora.v7i3.5355

Elamin, M. Z., Ilmi, K. N., Tahrirah, T., Zarnuzi, Y. A., Suci, Y. C., Rahmawati, D. R., Dwi P., D. M., Kusumaardhani, R., Rohmawati, R. A., Bhagaskara, P. A., \& Nafisa, I. F. (2018). Analisis Pengelolaan Sampah Pada Masyarakat Desa Disanah Kecamatan Sreseh Kabupaten Sampang. Jurnal Kesehatan Lingkungan, 10(4), 368-375. https://doi.org/10.20473/jkl.v10i4.2018.368-375

Intara, Y. I., Sapei, A., Erizal, Sembiring, N., \& Djoefrie, M. H. B. (2011). Pengaruh Pemberian 
Bahan Organik Pada Tanah Liat Dan Lempung Berliat Terhadap Kemampuan Mengikat Air. Jurnal Ilmu Pertanian Indonesia, 16(2), 130-135. https://journal.ipb.ac.id/index.php/JIPI/article/view/6457

Rahmawati, A., Kurniahu, H., \& Sriwulan. (2017). Teknik Pengomposan Kertas Bekas Dan Limbah Organik Rumah Tangga Menggunakan Starter Cairan Rumen Sapi. Jurnal $\begin{array}{llll}\text { Biologi \& Pembelajarannya, 24-31. } & \text { 4(2), }\end{array}$ https://ojs.unpkediri.ac.id/index.php/biologi/article/view/929

Sholihah, A., \& Nurhidayati. (2018). IbM Kelompok Tani Hortikultura Dalam Rangka Perbaikan Manajemen Produksi Kompos. Jurnal Inovasi Hasil Pengabdian Masyarakat (JIPEMAS), 1(2), 94-104. https://doi.org/10.33474/jipemas.v1i2.1513

Suwatanti, E., \& Widiyaningrum, P. (2017). Pemanfaatan MOL Limbah Sayur pada Proses Pembuatan Kompos. Jurnal MIPA, 40(1), 1-6. https://journal.unnes.ac.id/nju/index.php/JM/article/view/12455

Trivana, L., \& Pradhana, A. Y. (2017). Optimalisasi Waktu Pengomposan dan Kualitas Pupuk Kandang dari Kotoran Kambing dan Debu Sabut Kelapa dengan Bioaktivator PROMI dan Orgadec. Sain Veteriner, 35(1), 136-144. https://doi.org/10.22146/jsv.29301 